\title{
Occurrence of trace metals of toxicological potential in common grass African foxtail (Cenchrus ciliaris)
}

\section{Omotayo R. Awofolu, Hilia Iikela, Charmaine Jansen, Joshua Hidinwa}

\author{
Namibia University of Science and Technology, 13 Storch Street, 264 Windhoek, Namibia
}

Received: 15 August 2017

Accepted: 27 October 2017

Published online: 30 December 2017

\begin{abstract}
Anthropogenic activities often result in the introduction of noxious contaminants into the environment with resultant distribution and transfer across the food chain. This study reports on the level of trace metals $(\mathrm{Cd}, \mathrm{Pb}, \mathrm{Cu}$ and $\mathrm{Zn}$ ) in African foxtail (Cenchrus ciliaris) plant; widely referred to as "common grass" and possible implication across the food chain. Plant samples were collected from stratified study area, processed and analysed using validated acid leaching protocols. Instrumental analysis of the metallic content was by ICP-OES. Quality assurance of the analytical protocol revealed its' applicability to the environmental samples through metallic recoveries $(n=3)$ in the range of $85.6-91 \%$. The overall mean concentration of analysed metals in samples ranged from $9.34 \mathrm{mg} / \mathrm{kg}-38.6$ $\mathrm{mg} / \mathrm{kg} ; 64.2 \mathrm{mg} / \mathrm{kg}-105.2 \mathrm{mg} / \mathrm{kg} ; 0.28 \mathrm{mg} / \mathrm{kg}-0.73 \mathrm{mg} / \mathrm{kg}$ and $0.54 \mathrm{mg} / \mathrm{kg}-16.3 \mathrm{mg} / \mathrm{kg}$ for $\mathrm{Cu}, \mathrm{Zn}, \mathrm{Cd}$ and $\mathrm{Pb}$ respectively across SCP1-SCP4. Incremental order of analysed trace metals across the SCPs were $\mathrm{Cu}$ : $\mathrm{SCP} 1>\mathrm{SCP} 2>\mathrm{SCP} 3>\mathrm{SCP} 4$; $\mathrm{Zn}$ : $\mathrm{SCP} 1>\mathrm{SCP} 2>\mathrm{SCP} 3>$ SCP4; Cd: SCP1>SCP2>SCP3 = SCP4 and Pb: SCP1>SCP2>SCP3>SCP4. Strong correlation $(r>0.99)$ was obtained between all the analysed trace metals. Significant difference at $(\mathrm{p}<0.05)$ was found between the analysed metals and SCP 1 while those between the metals and SCPs 2- 4 were non-significant. Accumulation of these metals in ruminants and transfer across the food chain is most probable.
\end{abstract}

Keywords: pollution, trace metals, anthropogenic, Namibia, african foxtail

\section{Introduction}

Contamination of the environment by noxious substances as a result of anthropogenic activities is a worldwide phenomenon (Fashola et al. 2016). Effect of these activities has been known to be deleterious to human and environmental health (Abbas et al. 2010). Toxic trace metals such as Lead $(\mathrm{Pb})$, Cadmium $(\mathrm{Cd})$, Mercury $(\mathrm{Hg})$ and Arsenic (As) are one of the categories of xenobiotic substances which are non-essential and have no physiological benefit to humans and other living organisms. They find their way into the environment through the dumping of solid waste materials containing these metals and through atmospheric deposition. Of particular concern is the presence of high level of these toxic metals in soil which can be taken up by plants. This is as a result of serious health implications

\footnotetext{
${ }^{*}$ Corresponding author: O. R. Awofolu

e-mail: orawofolu3@yahoo.com
} 
across the food chain. The level of pollution usually dictates the rate of bio-concentration and bioaccumulation of these metals in plants. Lower and more vulnerable living organisms such as plants, insects, earthworm and others become the first recipient of these metals with antecedent health problems. Toxic metals have been reported to be responsible for the death of lower organisms (Namieśnik et al. 2011) and the ecosystems serve as the reservoir of these contaminants. Soil, as an ecosystem, has been described as sink for toxic substances including trace metals (Wuana et al. 2011) and its contamination has resulted in metal transfer across the food chain (Zahir et al. 2009; Rajakarun et al. 2015).

Of major concern is the uptake of trace metals by plants and subsequent transfer to other organisms across the food ladder. Studies involving the transfer of toxic metals from plants to other living organisms have been reported (Roy and McDonald 2015). Accumulation of toxic metals by plants and subsequent consumption of these plants by ruminants and humans are of significant health implications. In rural communities where subsistence agricultural practices take place including rearing of goats and sheep, these animals are usually seen grazing on widely disperse plants generally referred to as common grass or weed. Consumption of trace metals containing grasses by ruminants may result in the accumulation of these metals in the milk and tissues of the animals with potential transfer to human upon consumption. Polluted soil by toxic metals will lead to losses in agricultural yield as well as health hazards as they enter the food chain through plant or animal products (Al-Najar et al. 2015).

One of the common and widely available plants that are eaten by ruminants is the African foxtail (Cenchrus ciliaris) which is categorised as weed due to its wild dispersal and growth. Ruminants are commonly found grazing on this plant on farms and along roadside in many developing countries including Namibia. Polluted soil serves as a medium through which toxic trace metals enter the food chain (Balkhair and Ashraf 2016). Significant amounts of trace metals such as $\mathrm{Cd}$ and $\mathrm{Pb}$ can be transferred from contaminated soil to plants and grass, causing accumulation of these potentially toxic metals in grazing ruminants. Accumulation of toxic metals in ruminants can potentially affect the health of these animals as well as that of humans from the consumption of heavy metal laden milk and animal tissues.

Trace metals, such as $\mathrm{As}, \mathrm{Cd}$ and $\mathrm{Pb}$, are of concern because they are readily transferred across the food chains. These metals do not have any beneficial biological function to man. Hence, this study examined possible prevalence of selected trace metals $(\mathrm{Cu}, \mathrm{Zn}, \mathrm{Cd}$ and $\mathrm{Pb})$ of toxicological potential in a common grass, botanically referred to as African foxtail (Cenchrus ciliaris). This was with a view of assessing possible metallic transfer from the plant to ruminants which are usually seen grazing along road sides and on private land and farms. Both subsistent and commercial agricultural practices including animal husbandry are common in the study area.

\section{Materials and Methods}

\subsection{Study area}

The study was conducted within the local municipal area in the Northern part of Namibia with the co-ordinates altitude of 1, $266 \mathrm{~m}$; latitude -19, 2333 (1913'59.880'’S) and longitude 17, 7167 $\left(1743^{\prime} 0.120^{\prime \prime} \mathrm{E}\right)$ and about 19, 840 inhabitants. Major commercial activities in the area include agriculture, industrial and construction. The study area was stratified into four stratum and samples collected randomly from each stratum named as sample collection points (SCPs). Hence the location of SCP1 with the co-ordinate: S19 $13^{\prime} 58.8^{\prime \prime}$; E017 $42^{\prime} 35.7^{\prime \prime}$ is in the north-western part of the study area and consist mainly of residences. The SCP2 with co-ordinate of S 19 $14^{\circ}$ '41.7'; E $017^{\circ} 43^{\prime} 12.0^{\prime \prime}$ is in the north-eastern section of the study area and is characterized by a mixture of residential and industrial activities. The SCP3 is in the south-western part of the area, consisting mostly also of 
residence with the co-ordinate of: S19 $15^{\prime}$ ' 21.6"; E $017^{\circ} 42^{\prime}$ 08.5" while the SCP 4 with the co-ordinate $\mathrm{S} 19^{\circ} 15^{\prime} 38.5^{\prime \prime} ; \mathrm{E} 017^{\circ} 42^{\prime} 43.2^{\prime \prime}$ is in the south-east of the study area and also consist of residences and commercial and agricultural activities. The co-ordinate of the control site (CS) is S22 $34^{\prime} 00.1^{\prime \prime}$; E017 $04^{\prime} 42.5^{\prime}$ and is located in Windhoek, the capital city of Namibia which is about $400 \mathrm{~km}$ away from the study area.

\subsection{Sampling, sample treatment and analysis}

The environmental sample utilised as trace metal indicator was the African foxtail grass (Cenchrus ciliaris) (Fig. 1A) which grow wildly in the area and are often consumed by ruminants. Plant samples were collected from the four (4) different sites represented as SCP1, SCP2, SCP3 and SCP4 between the periods of June to November 2015 using stratified random sampling within each stratum. Sampling was conducted at six (6) different periods with a view of assessing possible trend in trace metal level within and across the four sample collection sites. Control samples were collected from an area in Windhoek which is about $400 \mathrm{~km}$ distance away from sampling site. This area is characterised by very low anthropogenic activities. Pieces of plant samples were cut from each sampling site with the aid of clean stainless steel knife. These were placed in transparent plastic zipper bags, labelled and taken to the laboratory for further treatment and analysis.

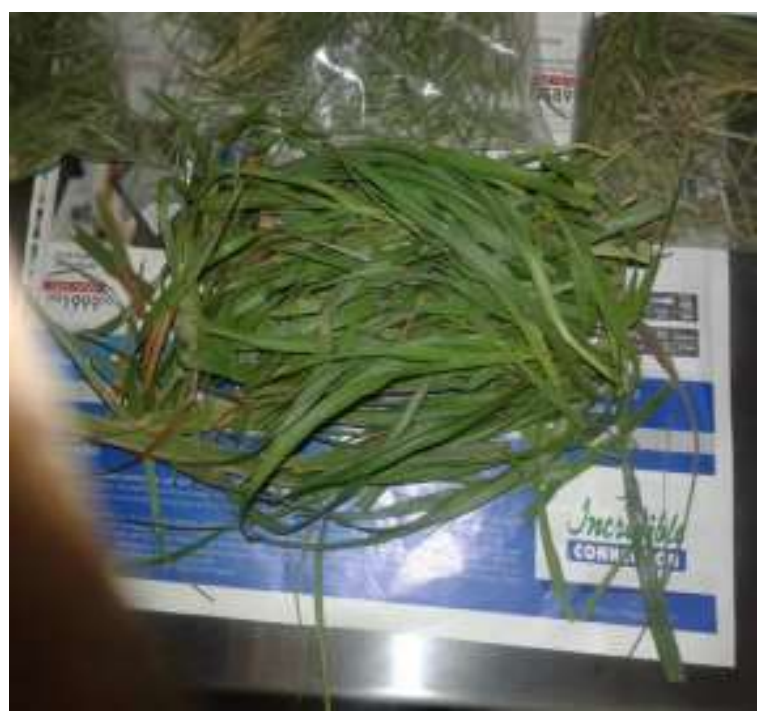

Fig. 1 (a) Freshly collected grass sample.

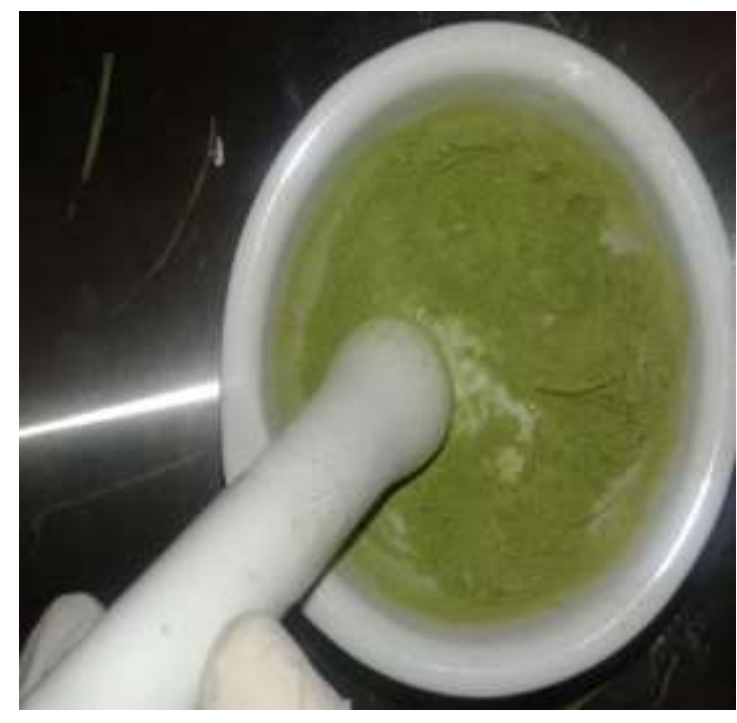

Fig. 1(b) Pulverised dried grass samples.

Deposits of soil particles on plant samples were removed by rinsing with distilled water. The plants were cut into smaller pieces with clean stainless scissors, placed in crucible and dried in the oven at $120^{\circ} \mathrm{C}$ for $24 \mathrm{~h}$. The dried samples were grinded in clean mortar and pestle and then sieved using 0.63 $\mu \mathrm{m}$ sieve. All metal determinations were based on the final fine powdery samples (Fig. 1B). Metallic content in plant samples were extracted through mineral acid digestion protocol as previously described (Awofolu 2005). Quality assurance of the analytical process was by standard metal addition and quantification in all cases was by Inductively-Coupled Plasma Emission Spectroscopy (ICP-OES). Briefly, $0.5 \mathrm{ppm}$ of $\mathrm{Cd}, \mathrm{Pb}, \mathrm{Cu}$ and $\mathrm{Zn}$ metals were added to $0.5 \mathrm{~g}$ of pre-digested plant sample in a 100$\mathrm{ml}$ beaker and digested with $5 \mathrm{ml}$ of conc. $\mathrm{HNO}_{3}$ and $2 \mathrm{ml}$ of $\mathrm{HClO}_{4}$ on low heat until the volume is about $2 \mathrm{ml}$. The content was allowed to cool, filtered into $50 \mathrm{ml}$ standard flask using $0.45 \mu \mathrm{m}$ Millipore Filter paper and then made to volume with deionized water. Triplicate digestion was carried out. 
O. R. Awofolu et al.

\subsection{Statistical analysis}

The levels of trace metals in grass samples were determined from four (4) sections of the study area as well as the control site (CS). The CS area is devoid of anthropogenic activities that are typical in the study area. Use of similar protocols in environmental pollution studies has been reported (Fagbote and Olanipekun 2010). Two-factor analysis of variance (ANOVA) was applied considering the extent of grass contamination with respect to the level of each trace metal in grass and the level at the four SCPs. In this case, possible statistical significance between the trace metals and the sample collection sites will be established. Significance level of $\mathrm{P}<0.05$ was used throughout the study. Pearson Correlation Coefficient analysis ( $r$ ) was conducted and applied to trace metal data in order to verify possible inter-elemental correlation.

\section{Results and Discussion}

\subsection{Quality assurance of the analytical process}

The reliability of applied protocol for trace metal analysis in plant samples was assured through the percentage $(\%)$ recovery of respective standard metals. Obtaining recovery values with the range of $85.6-91 \%$ validates the outcome of the experimental process as shown in Tab. 1.

Tab. $1 \%$ Recoveries $( \pm \mathrm{SD})$ of metals $(\mathrm{n}=3)$ from spiked plant sample.

\begin{tabular}{ccc}
\hline Metals & Spiked conc. $(\mu \mathrm{g} / \mathrm{ml})$ & \% Recoveries \\
\hline $\mathbf{C u}$ & 0.5 & $91.0 \pm 0.02$ \\
$\mathbf{Z n}$ & 0.5 & $88.0 \pm 0.05$ \\
$\mathbf{C d}$ & 0.5 & $86.0 \pm 0.09$ \\
$\mathbf{P b}$ & 0.5 & $85.6 \pm 0.05$ \\
\hline
\end{tabular}

Similar applicable \% recoveries of 80-120 \% (McComb et al. 2014), $86-119 \%$ (Şenilă et al. 2011) and $96.9-110 \%$ (Ishak et al. 2015) of trace metals analysis in plants have been reported.

\subsection{Level of analysed trace metals $(\mathrm{Cu}, \mathrm{Zn}, \mathrm{Cd}$ and $\mathrm{Pb})$ in African foxtail (Cenchrus ciliaris)}

The level of trace metals in the environment have increased tremendously mostly as a result of human activities. Elevated levels of these metals are detrimental to living organisms and some such as Cd has been implicated in endocrine disrupting activities (Nkoom et al. 2013) and thus have no physiological usefulness to humans and wildlife.

Assessment of the level of analysed toxic trace metals in the "common grass" plant sample (African foxtail) was conducted with a view of reflecting on possible impact across the food chain since ruminants are generally seen to be feeding on the plant. Although trace metals are said to be natural constituents of the earth's crust, elevated level in the environment has been attributed to anthropogenic activities (Tchounwou et al. 2012). Human activities such as petro-chemical (Afnan 2015), agricultural (Toth et al. 2016) and industrial (Ekong and Edem 2014) processes have been reported to contribute to elevated levels of trace metals in the environment.

In this study, analysed trace metals were detected in plant samples at all SCPs and across the six periods of assessment. The mean concentration of trace metals at SCP1, SCP2, SCP3 and SCP4 are presented in Tab. $2-5$ respectively across the sampling periods.

In Tab. 2, the mean concentration of trace metals at SCP1 and across the sampling period were $38.6 \mathrm{mg} / \mathrm{kg} ; 105.2 \mathrm{mg} / \mathrm{kg} ; 0.73 \mathrm{mg} / \mathrm{kg}$ and $16.3 \mathrm{mg} / \mathrm{kg}$ for $\mathrm{Cu}, \mathrm{Zn}, \mathrm{Cd}$ and $\mathrm{Pb}$ respectively. At this SCP1, the highest metallic level was recorded at SP1 for all metals with the exception of Pb which was obtained 
O. R. Awofolu et al.

during SP2. The high metallic level obtained at this sample collection point might be due to higher number of anthropogenic activities in this area. Petrochemical and industrial activities are noted in this area. The influence of petrochemical industries on environmental metallic burden has been report (Abdullah et al. 2012).

Tab. 2 Results of heavy-metal concentrations (mg/kg; dry wt.) in grass samples in July 2015; n=24.

\begin{tabular}{|c|c|c|c|c|c|c|}
\hline & & \multicolumn{2}{|c|}{$\mathbf{C u}$} & Zn & Cd & $\mathbf{P b}$ \\
\hline & & Mean & SD & Mean SD & Mean SD & Mean SD \\
\hline \multirow[t]{6}{*}{ SCP1 } & SP1 & 84.6 & 12.0 & $141.0 \quad 21.2$ & $1.25 \quad 0.12$ & $13.8 \quad 2.5$ \\
\hline & SP2 & 39.5 & 1.42 & $129.4 \quad 22.1$ & $1.10 \quad 0.04$ & $28.3 \quad 1.8$ \\
\hline & SP3 & 46.7 & 2.31 & $125.3 \quad 32.6$ & $0.75 \quad 0.12$ & $17.6 \quad 3.1$ \\
\hline & SP4 & 6.05 & 0.14 & $62.3 \quad 11.4$ & $\begin{array}{ll}0.25 & 0.02\end{array}$ & $2.10 \quad 0.2$ \\
\hline & SP5 & 49.4 & 2.02 & $120.2 \quad 19.8$ & $0.70 \quad 0.03$ & $25.2 \quad 3.1$ \\
\hline & SP6 & 5.55 & 0.11 & $\begin{array}{ll}52.9 & 12.3\end{array}$ & $\begin{array}{ll}0.35 & 0.05\end{array}$ & $10.7 \quad 1.2$ \\
\hline Mean & 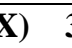 & & & 105.2 & 0.73 & 16.3 \\
\hline
\end{tabular}

$\mathrm{SCP}=$ Sample collection point; $\mathrm{SP}=$ Sample period

The mean concentrations of analysed trace metals at SCP3 and across SPs were $14.7 \mathrm{mg} / \mathrm{kg}$ $(\mathrm{Cu}) ; 74.4 \mathrm{mg} / \mathrm{kg}(\mathrm{Zn}) ; 0.45 \mathrm{mg} / \mathrm{kg}(\mathrm{Cd})$ and $3.15 \mathrm{mg} / \mathrm{kg}(\mathrm{Pb})$ as shown in Tab. 3. At this site, highest level of all trace metals across the SPs were obtained during SP4. Possible increase in anthropogenic activities during this period compared to others might account for this increase as well as contribution from atmospheric depositions. Atmospheric dust deposition has been reported to significantly contribute to the level of trace elements in the environment (Fernández et al. 2017).

Tab. 3 Results of heavy metal concentrations (mg/kg, dry wt.) in grass samples in August 2015; n=24.

\begin{tabular}{llllllllll}
\hline & & \multicolumn{2}{c}{ Cu } & \multicolumn{2}{c}{ Zn } & \multicolumn{2}{c}{ Cd } & \multicolumn{2}{c}{ Pb } \\
\cline { 2 - 10 } SCP2 & Mean SD & Mean & SD & Mean SD & Mean SD \\
\hline & SP1 & 14.20 & 2.1 & 71.15 & 23.2 & 0.55 & 0.05 & 1.20 & 0.06 \\
& SP2 & 12.45 & 0.3 & 9.30 & 12.4 & 0.40 & 0.12 & 4.00 & 0.12 \\
& SP3 & 14.20 & 3.2 & 58.30 & 8.9 & 0.30 & 0.07 & 1.30 & 0.03 \\
& SP4 & 23.90 & 10.1 & 142.4 & 15.7 & 0.60 & 0.03 & 8.95 & 0.25 \\
& SP5 & 12.15 & 1.5 & 47.85 & 10.6 & 0.35 & 0.15 & 1.65 & 0.17 \\
& SP6 & 11.20 & 0.2 & 37.55 & 5.7 & 0.50 & 0.03 & 1.80 & 0.08 \\
\hline Mean conc. $(\mathbf{~})$ & $\mathbf{1 4 . 7}$ & $\mathbf{7 4 . 4}$ & $\mathbf{0 . 4 5}$ & & $\mathbf{3 . 1 5}$ & \\
\hline
\end{tabular}

$\mathrm{SCP}=$ Sample collection point; $\mathrm{SP}=$ Sample period

Results of analysed trace metals at SCP3 are as shown in Tab. 4. The mean metal concentrations were in the order of $67.7 \mathrm{mg} / \mathrm{kg}(\mathrm{Zn}) ; 12.0 \mathrm{mg} / \mathrm{kg}(\mathrm{Cu}) ; 2.09 \mathrm{mg} / \mathrm{kg}(\mathrm{Pb})$ and $0.28 \mathrm{mg} / \mathrm{kg}(\mathrm{Cd})$. The highest level of analysed metals across the SPs were $\mathrm{Zn}$ (SP4) > Cu (SP5) > Pb (SP6) > Cd (SP2; SP5). Hence, the metallic impact varied across the SPs with no single period recording the highest level of analysed metals.

In Tab. 5, the mean level of analysed metals obtained at SCP 4 were $0.54 \mathrm{mg} / \mathrm{kg}$ of Cu; 64.2 $\mathrm{mg} / \mathrm{kg} \mathrm{Zn} ; 0.28 \mathrm{mg} / \mathrm{kg} \mathrm{Cd}$ and $0.54 \mathrm{mg} / \mathrm{kg}$ of Pb. At this site, the highest level of analysed metals was obtained during SP5. Again, possible increase in anthropogenic activities and influence from environmental factors such as atmospheric deposition of metals might have contributed to this increase when compared to same period at other SCPs.

In terms of individual values and significant contributions of analysed trace metals across the SPs during this study, values of $84.6 \mathrm{mg} / \mathrm{kg}$ (SP1), $49.4 \mathrm{mg} / \mathrm{kg}$ (SP5) and $46.7 \mathrm{mg} / \mathrm{kg}$ (SP3) of Cu were obtained (Tab. 2). These values were above the Safety Limit (SL) of $40 \mathrm{mg} / \mathrm{kg}$ of $\mathrm{Cu}$ in plant (WHO/FAO 2007). At this above SL, possible bio-concentration and bio-accumulation in ruminants that feed on these grasses can occur with dire consequence on human health. The meat and milk of the animals are one of the major sources of protein to the people. Bioaccumulation of $\mathrm{Cu}$ and other trace metals in the liver of cattle has been reported (Nwude et al. 2011). The overall mean range of $\mathrm{Cu}(9.34$ 
Environment, Earth and Ecology Vol. 1 No. 2 (2017), 52 - 61

O. R. Awofolu et al.

$\mathrm{mg} / \mathrm{kg}-38.6 \mathrm{mg} / \mathrm{kg}$, Tab. 6) across the SCPs and (8.86 mg/kg- $31.5 \mathrm{mg} / \mathrm{kg}$ across SPs (Tab. 7$)$ was lower than the MPL across the SPs.

Tab. 4 Results of heavy metal concentrations ( $\mathrm{mg} / \mathrm{kg}$, dry wt.) in grass samples in September 2015; $\mathrm{n}=24$.

\begin{tabular}{|c|c|c|c|c|c|c|c|}
\hline & \multirow{2}{*}{$\frac{\mathrm{Cu}}{\text { Mean SD }}$} & \multicolumn{2}{|c|}{$\mathbf{Z n}$} & \multicolumn{2}{|c|}{ Cd } & $\mathbf{P b}$ \\
\hline & & & \multicolumn{2}{|c|}{ Mean SD } & \multicolumn{2}{|c|}{ Mean SD } & Mean SD \\
\hline \multirow[t]{6}{*}{ SCP3 } & SP1 & 14.152 .5 & 90.50 & 21.1 & 0.30 & 0.04 & $\begin{array}{ll}0.10 & 0.03\end{array}$ \\
\hline & SP2 & 10.300 .9 & 50.60 & 13.2 & 0.35 & 0.02 & $2.55 \quad 0.41$ \\
\hline & SP3 & $\begin{array}{ll}12.30 & 0.7\end{array}$ & 40.45 & 7.8 & 0.20 & 0.07 & 3.110 .26 \\
\hline & SP4 & 11.150 .3 & 141.1 & 13.4 & 0.25 & 0.11 & $1.40 \quad 0.10$ \\
\hline & SP5 & $14.25 \quad 1.2$ & 54.90 & 6.7 & 0.35 & 0.06 & $2.06 \quad 0.13$ \\
\hline & SP6 & 10.101 .6 & 28.55 & 2.4 & 0.20 & 0.04 & $3.30 \quad 0.74$ \\
\hline \multicolumn{2}{|c|}{ Mean conc. $(\mathrm{X})$} & & 67.7 & & 0.28 & & 2.09 \\
\hline
\end{tabular}

$\overline{\mathrm{SCP}}=$ Sample collection point; $\mathrm{SP}=$ Sample period

Tab. 5 Results of heavy metal concentrations (mg/kg, dry wt.) in grass samples in October 2015; $\mathrm{n}=24$.

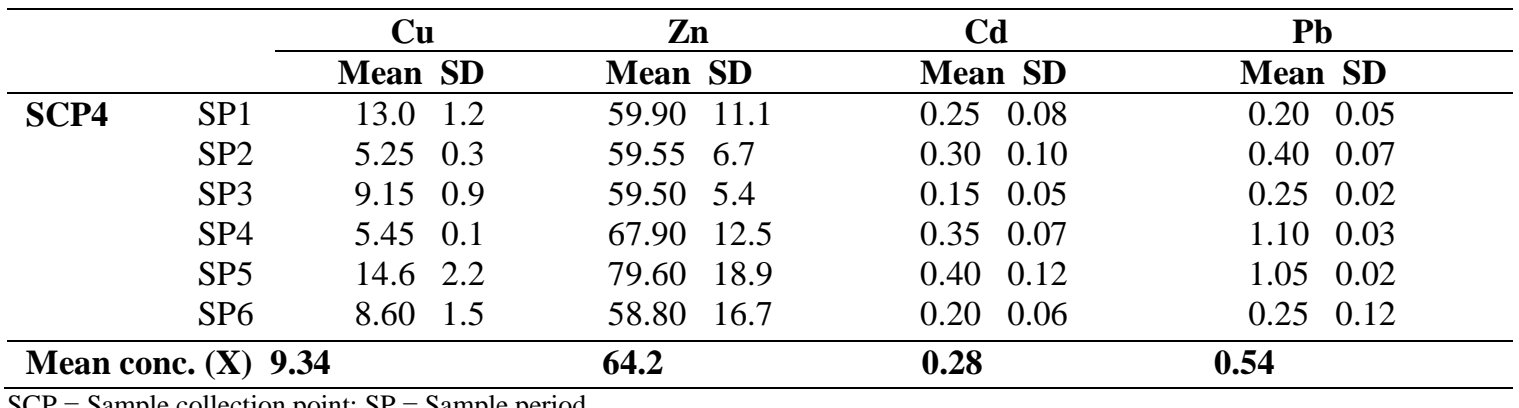

Tab. 6 Overall mean conc. (mg/kg; dry wt.) of metals in grass samples at all SCPs.

\begin{tabular}{lllllllll}
\hline & \multicolumn{1}{c}{ Cu } & \multicolumn{2}{c}{ Zn } & \multicolumn{2}{c}{ Cd } & \multicolumn{2}{c}{ Pb } \\
\hline SCP & Mean SD & Mean & SD & \multicolumn{2}{c}{ Mean } & SD & \multicolumn{2}{c}{ Mean SD } \\
SCP1 & 38.6 & 3.40 & 105.2 & 9.41 & 0.73 & 0.31 & 16.3 & 1.52 \\
SCP2 & 14.7 & 2.13 & 74.4 & 4.32 & 0.45 & 0.14 & 3.15 & 0.23 \\
SCP3 & 12.0 & 1.12 & 69.1 & 2.84 & 0.28 & 0.11 & 2.09 & 0.13 \\
SCP4 & 9.34 & 2.01 & 64.2 & 2.16 & 0.30 & 0.08 & 0.54 & 0.15 \\
CS & $\mathbf{4 . 6}$ & $\mathbf{0 . 1 8}$ & $\mathbf{3 1 . 7}$ & $\mathbf{2 . 3 7}$ & $\mathbf{0 . 0 5}$ & $\mathbf{0 . 0 2}$ & $\mathbf{0 . 0 5}$ & $\mathbf{0 . 0 3}$
\end{tabular}

SCP = Sample Collection Point; $\mathrm{CS}=$ Control Site

However, all the levels obtained were higher than $4.60 \mathrm{mg} / \mathrm{kg}$ of $\mathrm{Cu}$ obtained at the control site (CS). The high level of $\mathrm{Cu}$ obtained at SCP1 compared to the others might be due to the fact that more anthropogenic events such as industrial activities are observed in this area. The impact of elevated levels of trace metals in these grasses is not only on possible transfer across the food chain to human but also on the health of ruminants. Trace metals have been reported to accumulate in kidney and liver of ruminants thereby causing serious damage (More et al. 2015). $\mathrm{Cu}$ is a trace metal that is caught between the concept of essentiality and toxicity. It is regarded as an essential metal as a result of the role it plays in plant growth and as co-factor in metallo-protein activities. However, high level of $\mathrm{Cu}$ has been found to inhibit cellular electron transport during photosynthetic processes in plants (Yruela 2005).

Zinc (Zn) just like $\mathrm{Cu}$ plays some role in human physiology through utilization as food supplement by sport active individual for higher muscular mass (Haase et al. 2010). However, Zn has been reported to be toxic at higher doses (Osuna-páez et al. 2017). Although trace metals including $\mathrm{Zn}$ are said to be natural constituents of the earth's crust, anthropogenic activities such as the dumping of waste cans, lubricating oils and tyres which contain zinc additives on soil ecosystem may contribute to elevated level of this metal in the environment (Cocârţă et al. 2016). The metal was also detected 
in all analysed plant samples. The highest overall mean level of $\mathrm{Zn}$ across the SCPs and SPs were obtained at SCP1 and SP1. This might be due to higher level anthropogenic activities, hence higher impact in terms of contribution to environmental metallic load.

Tab. 7 Overall mean concentration of heavy metal $(\mathrm{mg} / \mathrm{kg})$ in grass samples for each sampling SP.

\begin{tabular}{lllll}
\hline & Cu & Zn & Cd & Pb \\
\hline SP1 & 31.5 & 90.6 & 0.59 & 3.81 \\
SP2 & 18.9 & 82.2 & 0.54 & 8.81 \\
SP3 & 20.6 & 70.9 & 0.35 & 5.61 \\
SP4 & 11.6 & 103.4 & 0.36 & 3.39 \\
SP5 & 22.6 & 75.6 & 0.45 & 7.49 \\
SP6 & 8.86 & 44.4 & 0.31 & 4.01 \\
\hline CS & $\mathbf{4 . 6 0}$ & $\mathbf{3 1 . 7 0}$ & $\mathbf{0 . 0 5}$ & $\mathbf{0 . 0 5}$ \\
\hline
\end{tabular}

$\mathrm{SCP}=$ Sample collection point; $\mathrm{SP}=$ Sample period; $\mathrm{CS}=$ Control site

The overall mean level of $64.2 \mathrm{mg} / \mathrm{kg}-105.2 \mathrm{mg} / \mathrm{kg}$ of Zn obtained across the SCPs (Tab. 6) and $44.4 \mathrm{mg} / \mathrm{kg}-103.4 \mathrm{mg} / \mathrm{kg}$ (Tab. 7) across the SPs were higher than the $60 \mathrm{mg} / \mathrm{kg}$ Safety Limit (SL) of $\mathrm{Zn}$ in plant (WHO/FAO 2007). These ranges were also higher than the values of $31.7 \mathrm{mg} / \mathrm{kg}$ of $\mathrm{Zn}$ obtained at the CS. Although some lower individual values of $9.30 \mathrm{mg} / \mathrm{kg}$ (at SCP2 during SP2 and $28.6 \mathrm{mg} / \mathrm{kg}$ at SCP3 during SP6 were obtained, most were higher than the maximum permissible level (MPL). At this high level, possible bioaccumulation in ruminants can occur with continual consumption of the grass.

Cadmium $(\mathrm{Cd})$ is usually monitored in the environment due to its high toxicity at low doses and its health implications to human and wildlife. It has been associated with carcinogenicity and endocrine disrupting activities (Sultana 2017), hence monitoring of its level in the environment is highly essential especially its sources, distribution and possible transfer across the food chain. The overall mean concentration of Cd obtained in this study across the SCPs was $0.28 \mathrm{mg} / \mathrm{kg}-0.73 \mathrm{mg} / \mathrm{kg}$ as shown in Tab. 6 while that across the SPs was $0.31 \mathrm{mg} / \mathrm{kg}-0.59 \mathrm{mg} / \mathrm{kg}$ as presented in Tab. 7. All these ranges were higher than $0.05 \mathrm{mg} / \mathrm{kg}$ level obtained at the CS.

In a similar pattern with $\mathrm{Cu}$ and $\mathrm{Zn}$, the level of $\mathrm{Cd}$ was highest at the SCP1 as well as during $\mathrm{SP} 1$. The metal was also detected in all analysed samples. The prescribed safety limit (SL) of Cd in plant was $0.2 \mathrm{mg} / \mathrm{kg}$ (WHO/FAO 2007). The overall mean concentration of Cd across the SCPs as well as those across SPs was higher than this value. Obtained values for most of the individual analysed samples across SCP1 - SCP4 were also higher with the exception of the value of $0.15 \mathrm{mg} / \mathrm{kg}$ (SP3) at SCP4. In a related study, above SL of $0.72 \mathrm{mg} / \mathrm{kg}$ of Cd in Cynodon and $0.76 \mathrm{mg} / \mathrm{kg} \mathrm{Cd}$ in Sorghum grasses have been reported (Madejon 2002). Detection of $\mathrm{Cd}$ above safety limit in grass samples is quite worrisome in view of the health implication across the food chain. Continual foraging of this plant by ruminants and subsequent consumption of the ruminant by human has dire health implication considering the high toxicity of this metal. Thus, exposure to cadmium may result in adverse effects on a number of tissues including kidney, liver, bone, testes, the immune system and the cardiovascular system.

Toxicity of $\mathrm{Pb}$ is not in doubt as it has been found to be responsible for quite a number of ailments in humans such as chronic neurological disorders especially in foetuses and children. It was also detected in all the analysed plant samples. The overall mean level of $\mathrm{Pb}$ ranged from $0.54 \mathrm{mg} / \mathrm{kg}-$ $16.3 \mathrm{mg} / \mathrm{kg}$ across SCPs (Tab. 6) while those across SPs varied from $3.39 \mathrm{mg} / \mathrm{kg}-8.81 \mathrm{mg} / \mathrm{kg}$ (Tab. 7). The prescribed SL of Pb in plants by (WHO/FAO 2007) was $5.0 \mathrm{mg} / \mathrm{kg}$. Most of the values obtained at SCP1 were above the SL except $2.10 \mathrm{mg} / \mathrm{kg}$ obtained at SP4.

Furthermore, the overall mean value of $16.3 \mathrm{mg} / \mathrm{kg}$ of $\mathrm{Pb}$ across the SCPs and $8.81 \mathrm{mg} / \mathrm{kg}$ and $7.47 \mathrm{mg} / \mathrm{kg}$ across the SPs were also higher than the SL. All these values were above $0.05 \mathrm{mg} / \mathrm{kg}$ obtained at the CS. As with the other analysed metals, the highest level of Pb was also obtained at SCP1. The high values of $\mathrm{Pb}$ obtained in this study reflect an accumulation of this metal by the grass and 
O. R. Awofolu et al.

transfer across the food chain is highly possible given the fact that it is the widely available and cheap forage for these animals. Possible sources of $\mathrm{Pb}$ in the study area include atmospheric deposition from related industrial activities, legacy environmental concentration from previous use of leaded petrol by automobiles as well as old lead batteries wastes.

\subsection{Metal-Site Association and Inter-elemental correlation analysis}

Analysis of variance was applied to data in order to check possible association between the analysed trace metals and the sample collection points (SCPs). Statistical significant difference at ( $\mathrm{p}<$ 0.05) was found between the analysed metals and the SCP1 (Tab. 8).

Tab. 8 Result of the analysis of variance (ANOVA: 2 Factor) for travel metal level and the SCPs.

\begin{tabular}{llll}
\hline CSPs & n & $\boldsymbol{F}$-value & $P$-value \\
\hline SCP1 & 6 & 3.65 & 0.02 \\
SCP2 & 6 & 1.59 & 0.22 \\
SCP3 & 6 & 0.96 & 0.47 \\
SCP4 & 6 & 1.70 & 0.19 \\
\hline P $>0.05 ;$ n $=$ number of samples
\end{tabular}

However, the differences were not significant between the metals and SCPs 2- 4. The strong correlation $(r>0.99)$ obtained between all the analysed trace metals as shown in Tab. 9 was indicative of similar anthropogenic sources possibly from atmospheric deposition as metal-bound particulates emanating from industrial processes. Emissions from incomplete combustion of fuel from vehicles are another plausible source.

Tab. 9 Metal correlation matrix between trace metals in plant samples.

\begin{tabular}{lllll}
\hline & $\mathrm{Cu}$ & $\mathrm{Zn}$ & $\mathrm{Cd}$ & $\mathrm{Pb}$ \\
\hline $\mathrm{Cu}$ & 1 & & & \\
$\mathrm{Zn}$ & 0.9973 & 1 & & \\
$\mathrm{Cd}$ & 0.9670 & 0.9824 & 1 & \\
$\mathrm{~Pb}$ & 0.9997 & 0.9954 & 0.9609 & 1 \\
\hline
\end{tabular}

\section{Conclusion}

This study generally revealed the impact of and contribution of anthropogenic activities to the prevalence and high level of analysed trace metals in plant samples. This contribution was more reflected at the SCP1 where higher level of the trace metals was detected compared to other sites in the study area. This may be due to the higher level of anthropogenic activities with this area. Higher levels of analysed metals were also recorded during the SP1 and SP2 which could be due to an increase in anthropogenic activities during these periods. The mean and overall mean levels of all analysed metals were above those recorded at control sites as well as permissible level with the exception of few instances. This study generally revealed the contribution of the level of analysed trace metals in the environment as a result of human activities and the consumption of metal laden plans by ruminants may have dire health consequences for human.

\section{Acknowledgement}

Appreciation of the funding provided by the National Commission of Research, Science and Technology of Namibia and the Namibia University of Science and Technology (NUST) for the implementation of this research project. 
O. R. Awofolu et al.

\section{References}

Abbas M, Parveen Z, Iqbal M, Iqbal S, Ahmed M, Bhutto R (2010) Monitoring of toxic metals (cadmium, lead, arsenic and mercury) in vegetables of Sindh, Pakistan, J Engineering Sci. and Technol. 6, 60-65.

Abdullah MZ, Saat A, Hamzah Z (2012). Assessment of the impact of petroleum and petrochemical industries to the surrounding areas in Malaysia using mosses as bioindicator supported by multivariate analysis. Environ. Monit. and Assess. 184 (6): 3959-3969.

Afnan MF (2015) Heavy metal, trace element and petroleum hydrocarbon pollution in the Arabian Gulf: Review. J Assoc. of Arab Universities and Applied Sciences 17, 90-100.

Al-Najar H, Alrayes N, Dokhan A, Saqer A, Silmi R, Al-Kurdi S (2015) Assessing Heavy Metals Pollution in the Agricultural Lands of Gaza Strip that Has Undergone Three Successive Wars. American Journal of Environmental Protection 3 (4):151-158.

Awofolu OR (2005) A survey of trace metals in vegetation, soil and lower animal along some selected major roads in Metropolitan City of Lagos. Environ. Monit. and Assessment 105, 431-447.

Balkhair S, Ashraf MA (2016) Field accumulation risks of heavy metals in soil and vegetable crop irrigated with sewage water in western region of Saudi Arabia. Saudi J Biological Sciences 23 (1): S32-S44.

Cocârţă DM, Neamţu S, Reşetar-deac AM (2016) Carcinogenic risk evaluation for human health risk assessment from soils contaminated with heavy metals. Int. J of Environ Sci. and Technol. 13 (8): 2025-2036.

Ekong AU, Edem DI (2014) Impacts of industrial activities on soil and vegetation: A case study of aluminium smelting company of Nigeria (ALSCON). J. Wetlands Biodiversity 4, 23-33.

Fagbote EO, Olanipekun EO (2010) Evaluation of the Status of Heavy Metal Pollution of Soil and Plant (Chromolaena odorata) of Agbabu Bitumen Deposit Area, Nigeria. American-Eurasian Journal of Scientific Research 5 (4): 241-248.

Fashola MO., Ngole-jeme VM, Babalola OO (2016) Heavy Metal Pollution from Gold Mines: Environmental Effects and Bacterial Strategies for Resistance. Int. J. Environ. Res. Public Health 13(11):1047 doi: 10.3390/ijerph13111047.

Fernández GG, Bisquert DS, Castejon JMP (2017). The impact of atmospheric dust deposition and trace elements levels on the villages surrounding the former mining areas in a semi-arid environment (SE Spain). Atm. Int. 152, 256-269.

Haase H, Plum LM, Rink L (2010) The Essential Toxin: Impact of Zinc on Human Health. Int. J Environ Res Public Health 7 (4): 1342-1364.

Ishak I, Rosli FD, Mohamed J, Ishmael MFM (2015) Comparison of Digestion Methods for the Determination of Trace Elements and Heavy Metals in Human Hair and Nails. Malays J Med Sci. 22 (6): 11-20.

Madejon P, Murillo JM, Maranon T, Cabrera F, Lopez R (202) Bioaccumulation of As, Cd, Cu, Fe and $\mathrm{Pb}$ in wild grasses affected by the Aznalcollar mine spill (SW Spain). The Science of the Total Environment 290, 105-120.

McComb JQ, Rogers C, Han FX, Tchounwou PB (2014) Rapid screening of heavy metals and trace elements in environmental samples using portable X-ray fluorescence spectrometer, A comparative study. Water, Air, and Soil Pollution 225 (12):2169 doi: 10.1007/s11270-014-2169-5.

More SJ, Canty MJ, Lane EA (2015) Cadmium exposure and consequence for the health and productivity of farmed ruminants. Research in veterinary Science 101, 132-139.

Namieśnik J, Skóra K, Konieczka P, Jakimska A (2011) Bioaccumulation of Metals in Tissues of Marine Animals, Part I: the Role and Impact of Heavy Metals on Organisms. Pol. J. Environ. Stud. 20 (5):1117-1125.

Nkoom M, Cobbina SJ, Kuni M (2013) Assessment of Endocrine Disrupting Trace Metals in River Samre at Samreboi in the Wassa Amenfi West District of the Western Region of Ghana. JWARP 5 (10): 983-992.

Nwude DO, Okoye PAC, Babayemi JO (2011) Assessment of Heavy Metal Concentrations in the Liver of Cattle at Slaughter during Three Different Seasons. Research Journal of Environmental Sciences 5, 288-294. 
O. R. Awofolu et al.

Osuna-páez F, Diaz-valdes T, Mariscal-Lagarda MM, Fierro-sanudo JF, Alarcon-Silvas SG, Leon-canedo JA (2017) Assessment of environmental loads of $\mathrm{Cu}$ and $\mathrm{Zn}$ from intensive inland shrimp aquaculture. Environ Monit and Assessment 189, 69, doi:10.1007/s10661-017-5783-z.4.

Rajakarun N, Gall JE, Boyd RS (2015) Transfer of heavy metals through terrestrial food webs: a review. Environ. Monit. Assessment 187, 201-219.

Roy M, McDonald LM (2015) Metal Uptake in Plants and Health Risk Assessments in MetalContaminated Smelter Soils. Land Degrad. Develop 26, 785-792.

Şenilă M, Şenilălă C, Roman C (2011) Evaluation of performance parameters for trace elements analysis in perennial plants using ICP-OES technique. J. Plant Develop. 18, 87-93.

Sultana MS, Yoshida S, Aono T, Yamazaki S, Rana S (2017) Health risk assessment for carcinogenic and non-carcinogenic heavy metal exposures from vegetables and fruits of Bangladesh. Cogent Environmental Science 3, doi.org/10.1080/23311843.2017.1291107.

Tchounwou PB, Yedjou CG, Patllola AK, Sutton DJ (2012) Heavy Metals Toxicity and the Environment EXS 101, 133-164.

Toth G, Da Silva MR, Montanarella L (2016) Heavy metals in agricultural soils of the European Union with implications for food safety. Environment International 88, 299-309.

WHO/FAO (2007) Joint FAO/WHO Food Standard Programme Codex Aliment Arius Commission $13^{\text {th }}$ Session. Report of the Thirty-Eight Session of the Codex Committee on Food Hygiene, Houston, United States of America, ALINORM 07/ 30/13.

Wuana RA, Felix E, Okieimen FE (2011) Heavy Metals in Contaminated Soils: A Review of Sources, Chemistry, Risks and Best Available Strategies for Remediation. ISRN Ecology 1-20, doi.org/10.5402/2011/402647.

Yruela I (2005) Toxic metals in plants. Braz. J. Plant Physiol. 7 (1): 145-156.

Zahir E, Naqvi I, Uddin SH (2009) Market Basket Survey of selected metals in fruits from Karachi city (Pakistan). Journal of Basic and Applied Sciences 5 (2): 47-52. 